\title{
INFLUENCE OF FUNCTIONALIZED MULTI-WALLED CARBON NANOTUBES ON FILTERABILITY AND MECHANICAL PROPERTIES OF RAYON NANOCOMPOSITE FILAMENTS
}

\author{
Holia Onggo a ${ }^{\text {, }}$, Rike Yudianti a, Endang Ruchiat ${ }^{\text {b }}$ \\ ${ }^{a}$ Research Centre for Physics Indonesian Institute of Sciences, J1. Cisitu 21/154D, Bandung 40135, Indonesia \\ ${ }^{\mathrm{b}}$ Center for Pulp and Paper, Ministry of Industry, J1. Raya Dayeuhkolot No. 132, Bandung 40258, Indonesia \\ ${ }^{1}$ holi001@lipi.go.id
}

Diterima : 20 Maret 2013, Revisi akhir : 16 Mei 2013, Disetujui terbit : 30 Mei 2013

\begin{abstract}
PENGARUH FUNGSIONALISASI MULTIWALLED CARBON NANOTUBE
TERHADAP DAYA SARING DAN SIFAT MEKANIK DARI RAYON

NANOCOMPOSITE FILAMENTS
\end{abstract}

\begin{abstract}
ABSTRAK
Rayon nanocomposite filaments telah dibuat melalui proses pemilinan (spinning) dan koagulasi (coagulation) dari campuran $100 \mathrm{~mL}$ larutan functionalized carbon nanotube dispersion ( $\mathrm{FCNT}=0,72 \mathrm{~g}$ ), selulosa santat dalam larutan $\mathrm{NaOH}$ melalui proses viskosa. CNT di functionalisasi (FCNT) menggunakan campuran larutan asam $\left(\mathrm{H}_{2} \mathrm{SO}_{4} / \mathrm{HNO}_{3}, 3: 1 \mathrm{v} / \mathrm{v}\right)$. Pengaruh fungsionalisasi CNT pada pembuatan rayon nanocomposite filaments dipelajari dengan cara membandingkannya dengan CNT tanpa fungsionalisasi (nFCNT). Sifat fisik dan morfologi dari rayon-nanocomposite filaments dikarakterisasi menggunakan tenacity tester, photo micrograph, scanning electron microscope (SEM) dan transmission electron microscope (TEM). Viskosa FCNT memiliki daya saring (Kw) cukup baik yaitu 155, sedangkan viskosa nFCNT memiliki daya saring 1689 (tidak baik). Kekuatan mekanik dari FCNT-rayon nanocomposite filaments berturut turut adalah 3,01 g/denier (tenacity), dan 36,5\% (elongation), lebih baik dibandingkan dengan $n F C N T$-rayon nanocomposite filament : 2,72 g/denier (tenacity) dan 57,1\% (elongation).
\end{abstract}

Kata kunci: fungsionalisasi multi-walled carbon nanotubes, rayon-nanocomposite filament, sifat mekanik, daya saring, dispersi

\begin{abstract}
Carbon nanotube-rayon composite filaments was fabricated by spinning and coagulation of the mixture of $100 \mathrm{~mL}$ functionalized carbon nanotube dispersion (containing $0.72 \mathrm{~g} \mathrm{FCNT}$ ) and cellulose xanthate in $\mathrm{NaOH}$ solution using viscose process. In the process, CNT was functionalized using mixture of acidic solution $\left(\mathrm{H}_{2} \mathrm{SO}_{4} / \mathrm{HNO}_{3}, 3: 1 \mathrm{v} / \mathrm{v}\right)$. Influence of functionalized (FCNT) and non-functionalized carbon nanotubes (nFCNT) on the fabrication of rayon nanocomposite filament was studied. Physical and morphological properties of the nanocomposite filaments were characterized by single filament tenacity tester, photo micrograph, scanning electron microscope (SEM) and transmission electron microscope (TEM). Filterability and mechanical properties of FCNT-rayon nanocomposite filament greatly improved by reducing clogging constant from 1689 to 153 and increasing tenacity from 2.72 to $3.01 \mathrm{~g} /$ denier and decreasing elongation from 57.1 to $36.5 \%$ respectively compared with those of nFCNT-rayon nanocomposite filament.
\end{abstract}

Keywords: functionalized multi-walled carbon nanotubes, nanocomposite filament, mechanical properties, filterability, dispersion 


\section{INTRODUCTION}

Carbon nanotubes (CNTs) have much attention because of their unique mechanical, thermal and electrical properties since their discovery by Iijima (Iijima, 1991). These nano materials are very promising for development of cellulosebased composites fabrication such as CNTscellulose composite paper for electromagnetic shielding material (Imai et al., 2010; Fugetsu et al., 2008). Such CNT-cellulose composite fibers may use in multifunctional materials such as conducting textile fibers for electronic textiles applications (Yoon et al., 2006; Chen et al., 2009). In the fabrication of high quality CNTs-cellulose composites fibers with predictable and optimal performance, a homogeneous dispersion of the CNTs in the cellulose matrix is required. Several techniques have been used to disperse CNTs, e.g. ultrasonication, addition of surfactant (Clark et al., 2011) and chemical modification of the nanotube surface (Rausch et al., 2010). The appropriate method in finding well dispersed CNT solution is important role in manufacturing of CNT-based nanocomposite. The most common method of making cellulose fiber (Rayon fiber) is viscose process which involves derivatizing of cellulose with carbon disulphide followed by dissolution in sodium hydroxide (Moigne and Navard, 2010). Solution spinning of cellulose CNTs composites using ionic liquids have been fabricated (Sameer et al., 2009) and CNT-cellulose composite fiber using cellulose xanthate as solubilizing agent of CNTs have been fabricated (Wei et al., 2010), who treated $\mathrm{CNT}$ by $\mathrm{HNO}_{3}$ only. However in this study we used mixture of acidic solution $\left(\mathrm{H}_{2} \mathrm{SO}_{4} /\right.$ $\mathrm{HNO}_{3}, 3: 1 \mathrm{v} / \mathrm{v}$ ) to oxidized CNT and the influence of functionalized of MWCNT on filterability of the viscose and mechanical propterties of the obtained nanocomposite filament was studied.

\section{MATERIALS AND METHOD}

\section{Materials}

CNTs specified as multiwall carbon nanotube (MWCNT) were purchased from He-Ji (Hongkong) Company, Limited. The purity is, above $95 \%$, average outer diameter of $8-15 \mathrm{~nm}$ and length $10-30 \mu \mathrm{m}$ are reported. a commercial cationic surfactant cetyl-trimethylammonium bromide (CTAB, Sigma Aldrich with purity of
$99 \%$ ) was used as dispersion agent. $\mathrm{H}_{2} \mathrm{SO}_{4}$, (95$97 \%)$ and $\mathrm{HNO}_{3}(65 \%)$ were suplied by Aldrich. Dried pulp ("Kotlas" from Rusia, a cellulose $93 \%$, DP 700). Other materials such as $\mathrm{CS}_{2}$, $\mathrm{NaOH}, \mathrm{H}_{2} \mathrm{SO}_{4}, \mathrm{Na}_{2} \mathrm{SO}_{4}, \mathrm{ZnSO}_{4}$ are specified as industrial grade.

\section{Functionalization of CNTs}

CNTs $(2.5 \mathrm{~g})$ were immersed in a mixture of $60 \mathrm{~mL}$ of $\mathrm{H}_{2} \mathrm{SO}_{4} / \mathrm{HNO}_{3}(3: 1, \mathrm{v} / \mathrm{v})$, for $15 \mathrm{~min}$ put in ultrasound bath for $2 \mathrm{~h}$ and then refluxed for 6 $\mathrm{h}$ at $60^{\circ} \mathrm{C}$. The CNTs solutions were then filtered using polytetrafluoroethylene (PTFE) membrane with diameter $47 \mathrm{~mm}$ and the pore size of 0.45 $\mu \mathrm{m}$ (Cole Parmer). Washing was continuously conducted until neutral. Finally, the neutralized CNTs were oven-dried at $105^{\circ} \mathrm{C}$.

\section{Characterization of CNTs Dispersion by UV Spectrophotometer}

Dispersion of CNTs were characterized by UV spectrosphotometer (UV-1200 Shimadzu). Three samples of CNTs dispersion e.g. 1) nFCNT dispersion in CTAB solution 2) FCNT dispersion in water, and 3) FCNTs dispersion in CTAB solution were prepared to measure the stability of CNTs dispersion in water-CTAB solution at static condition. The sample solution was placed in the standing tubes and stored at room temperature for 5 days. Upper part of the stock solutions $(0.5$ $\mathrm{mL}$ ) was taken and diluted by a certain factor, resulting in certain MWCNTs concentration to be measured by UV spectrophotometer.

\section{Preparation of Cellulose Xanthate}

Dissolving pulp (125 g) containing 93\% a-cellulose was mercerized in $5 \mathrm{~L}$ of $18 \%(\mathrm{w} / \mathrm{v})$ $\mathrm{NaOH}$ at $25^{\circ} \mathrm{C}$ for $1 \mathrm{~h}$. After removing excess alkali solution by pressing, Alkali Cellulose was shredded and then air-incubated for $24 \mathrm{~h}$ at $20^{\circ} \mathrm{C}$. High concentration of $\mathrm{CS}_{2}(36 \%)$ was then added to provide cellulose xanthate.

\section{Preparation of CNTs-Cellulose Xanthate Viscose for Spinning}

Dispersion of functionalized (FCNTs) was prepared by suspending $1.8 \mathrm{~g}$ CNTs in $250 \mathrm{~mL}$ CTAB solution $(1.44 \%(\mathrm{w} / \mathrm{w})$ in water $)$. The 


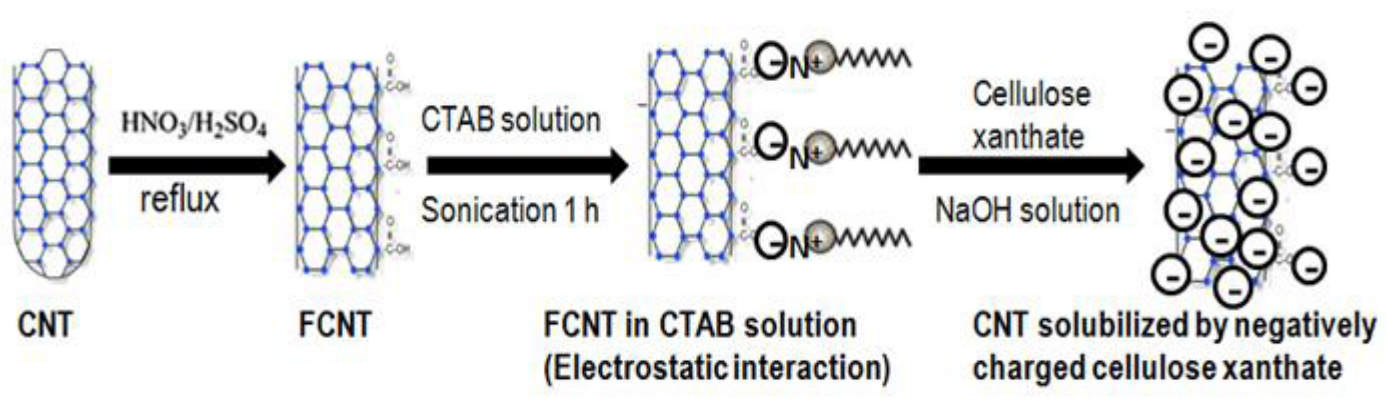

(a)

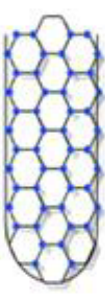

CNT

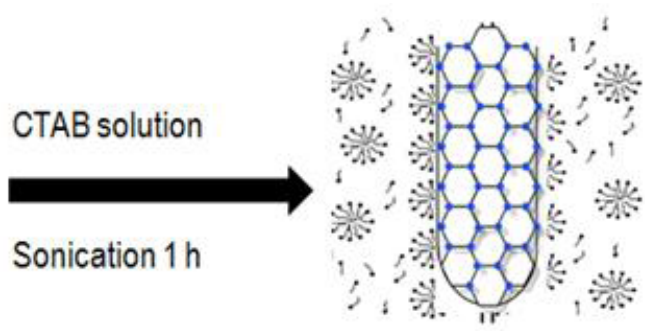

nFCNT solution

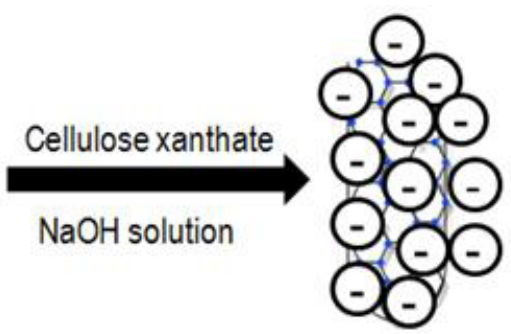

CNT solubilized by negatively charged cellulose xanthate

(b)

Figure 1. Schema Model Dissolving Process of Cellulose Xanthate and CNTs Dispersion in an Aqueous NaOH Solution (a) Functionalized CNT (b) Non Functionalized CNT

solution was sonicated by vibracell ultrasonicator, $750 \mathrm{~W}$ at $20 \mathrm{~Hz}$ for $1 \mathrm{~h}$ at room temperature. Cellulose xanthate and $100 \mathrm{~mL}$ of CNT solution containing $0.72 \mathrm{~g}$ CNT were dissolved in aqueous $\mathrm{NaOH}$ solution at $10^{\circ} \mathrm{C}$ for $4 \mathrm{hr}$. By this process, FCNTs-cellulose xanthate viscose was compared to non functionalized CNT.

Schema model in dissolving process of cellulose xanthate and CNTs dispersion in aqueous $\mathrm{NaOH}$ solution are shown in Fig. 1. (Clark et al., 2011; Rausch et al., 2010; Moigne and Navard, 2010; Rike et al., 2011; Shrivas and $\mathrm{Wu}, 2008)$.

\section{Filterability}

Filterability of CNT-viscose solutions were specified as clogging constant value $(\mathrm{Kw})$. In the testing CNT-viscose solution is introduced into cylindrical steel vessel and filtered through 3 layers of cotton fabric under pressure with the effective filter area of $8.77 \mathrm{~cm}^{2}$. The amount of filtrate was obtained within a filtering time from 0 to $20 \mathrm{~min}(\mathrm{P} 1)$ and 20 to $60 \mathrm{~min}(\mathrm{P} 2)$. Clogging constant $(\mathrm{Kw})$ was calculated with the following equation:

$\mathrm{KW}=100,000 \times(2-\mathrm{P} 2 / \mathrm{P} 1) /(\mathrm{P} 1+\mathrm{P} 2)$

Fabrication of CNT/Rayon Nanocomposite Filament by Wet Spinning

$\mathrm{CNT} /$ rayon nanocomposite filaments were fabricated using a wet spinning method. CNT/ viscose solution was forced through spinneret made of aurum $(\mathrm{Au})$ and platinum $(\mathrm{Pt})$ alloy consisting of 50 hole with $0.07 \mathrm{~mm}$ in diameter. Existing fine filaments of viscose were made in contact with coagulant in the spin bath of $160 \mathrm{~g} / \mathrm{L} \mathrm{H}_{2} \mathrm{SO}_{4}, 325 \mathrm{~g} / \mathrm{L} \mathrm{Na}_{2} \mathrm{SO}_{4}$ and $13.52 \mathrm{~g} / \mathrm{L}$ $\mathrm{ZnSO}_{4}$. The temperature of coagulation solution and viscose spinning speed were $45^{\circ} \mathrm{C}$ and 6.0 $\mathrm{cm}^{3} / \mathrm{min}$, respectively. The resulting filaments were washed using hot water. 


\section{Fiber Characterization}

\section{The Mechanical Properties of CNT/Rayon Nanocomposite Filaments}

Mechanical properties of single filaments were measured using single filament tenacity tester with a $20 \mathrm{~mm}$ gauge length at a cross bar rate of $20 \mathrm{~mm} / \mathrm{min}$. The tenacity and elongation of fibers were calculated in average of 25 time measurements. All measurement was conducted at room temperature and $65 \%$ relative humidity. All parameters were compared to regular rayon filament of Standar Nasional Indonesia (SNI1989).

\section{Morphological Surface of CNTs and CNT/ Rayon Nanocomposite Filament}

Influence of functionalization on the structure of CNTs were observed by TEM. Longitudinal and cross section surfaces of the CNT/rayon nanocomposite filaments (FCNT and nFCNT) were observed by scanning electron microscope (SEM) and transmission electron microscope (TEM). For SEM analysis, preparation of sample was carried out by embedding the fibers in epoxy matrix. These embedded fibers were broken in liquid nitrogen to retain their inherent morphology and was then coated with gold using a JEOL JSM-5600LV microscopy. For TEM, analysis CNT/rayon composite were embedded in PON812 resin. Ultrathin samples dissected using a Leica EM UC7-NT ultramicrotome with a diamond knife. Transmission Electron Microscope (TEM), a Jeol JEM 1400 were used to analyze the samples; the images produced were used to evaluate the cross-sectional shape of the CNT-rayon filaments.

\section{RESULTS AND DISCUSSION}

\section{Carbon Nanotube Functionalization}

The TEM image of nFCNT and FCNT are shown in Fig. 2. The impurities such as graphitic and residual catalytic metal particles of CNT was observed as black line color (Fig. 2a). Acid treatment removed rest of graphitic and residual catalytic metal particles of CNT as shown in Fig. 2b. In addition, acid treatment left some defect sites such as bends in the tube as indication of unsymetrical hexagonal carbon. This result in similar with the previous work (Rike et al., 2011). It means that carboxylic are formed on both the tips and the walls of the tubes.

\section{Stability of CNTs Dispersion}

Stability of CNT dispersion can be monitored by UV-spectroscopy. Dispersion of nFCNTs in CTAB solution, FCNTs-dispersion in water and FCNTs-dispersion in CTAB solution was observed as a function of time.

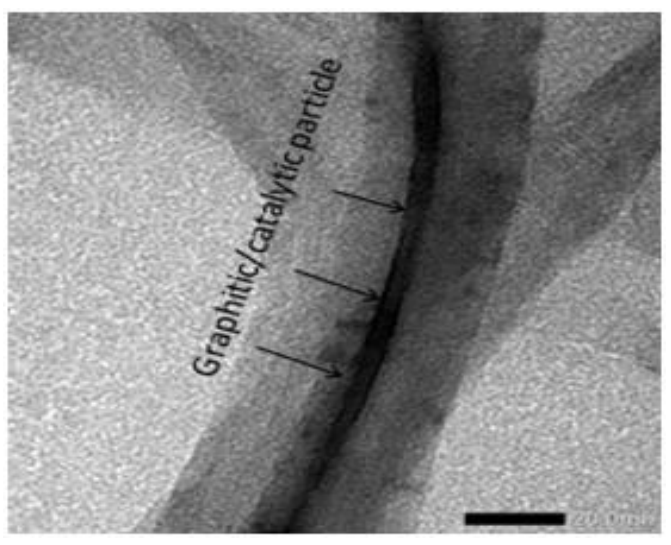

(a)

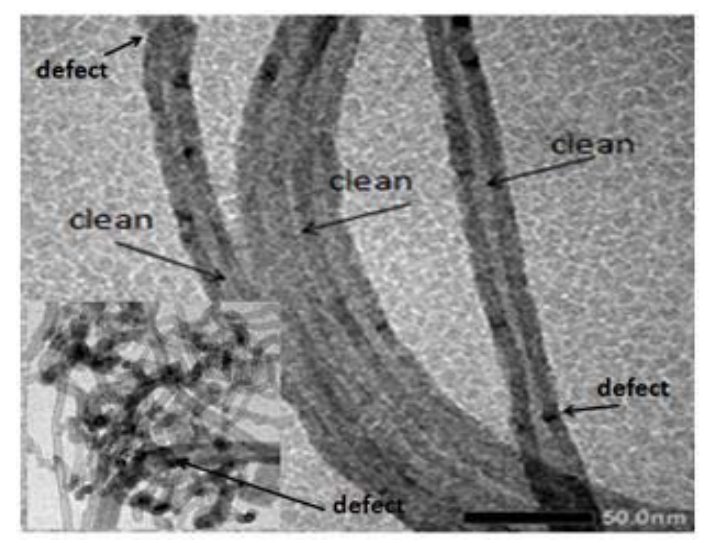

(b)

Figure 2. Morphological Surface of Carbon Nanotube : (a) nFCNTs (b) FCNTs 


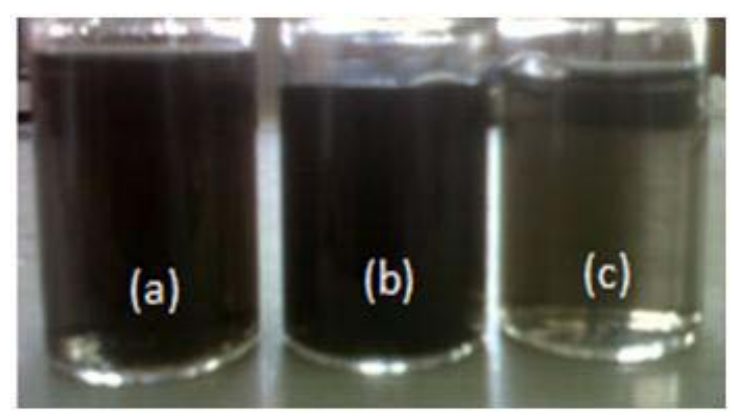

Figure 3 : The Dispersion of $\mathrm{nFCNT}$ in CTAB Solution (a); FCNT in Water (b); FCNT in CTAB Solution(c)

Based on absorbance at $\lambda=256 \mathrm{~nm}$, the dispersion of nFCNTs in CTAB solution, FCNTs in water and FCNTs in CTAB solution was $0.738,0.751$ and 0.161 , respectively. FCNT in water showed better dispersion than in CTAB solution. Dispersion of $\mathrm{nFCNT}$ in CTAB solution stable for 20 days. Black solution indicates well dispersion without any precipitation (Fig.3a, b). Good dispersion of nFCNT in CTAB solution was caused by wrapping of $\mathrm{CTAB}$ molecules surrouding nFCNTs. In the solution, FCNT visually seem relatively well dispersed solution. The well dispersion may be caused by ionization of FCNT. The surface of FCNT posses negative charge of carboxyl groups on the CNT surface which make them repulse each other because of the coulomb interaction. Cationic surfactants CTAB are organic compound containing one hydrophobic alkyl chain and a hydrophilic group containing positive charge. When FCNTs was dispersed in CTAB solution, an electrostatic interaction between FCNT and CTAB occurred (Shrivas and $\mathrm{Wu}, 2008$ ).

\section{The Composition of Viscose Solution}

The viscose solution of FCNTs-cellulose xanthate compose of $8.27 \%$ regenerable cellulose (based on total solution), 6.54\% NaOH (based on total solution) and $36 \% \mathrm{CS}_{2}$ (based on cellulose content of solution), $0.72 \%$ FCNTs (based on FCNT dispersion in CTAB solution). Whereas the viscose solution of nFCNTs-cellulose xanthate compose of $7.43 \%$ regenerable cellulose (based on total solution), $6.84 \% \mathrm{NaOH}$ (based on total solution) and $36 \% \mathrm{CS}_{2}$ (based on cellulose content of solution) and $0.72 \%$ FCNTs (based on FCNT dispersion in CTAB solution).

\section{Filterability of FCNTs}

A good filterability effect mainly comes from less gel particles of large size in viscose (Uneback et al., 1985). The lower value for $\mathrm{Kw}$-value the better filterability of viscose solution. The Kw of viscose solution prepared by the addition of FCNT is 155.2. On the other hand, the Kw of viscose solution prepared by the addition of $\mathrm{nFCNT}$ dispersion is 1689 . It means that functionalization of CNTs is able to reduce the formation of gel particles in the viscouse solution. Large size of gel particles using nFCNTs are graphitic catalytic particles (Fig.1).

\section{Mixing Processing of CNT-Cellulose Xanthate}

CTAB as cationic surfactant importantly contribute to make well-dispersed CNT solution in water via van der Waals forces to create longstable solution. Cellulose can react with carbon disulfide in alkaline solution to form water-soluble

Table 1. Mechanical Properties of FCNT-Rayon Nanocomposite and nFCNT-Rayon Nano Composite Filaments in The Dry an Wet State

\begin{tabular}{lcccc}
\hline \multirow{2}{*}{\multicolumn{1}{c}{ Filament }} & \multicolumn{2}{c}{ Tenacity $(\mathrm{g} /$ denier$)$} & \multicolumn{2}{c}{ Elongation $(\%)$} \\
\cline { 2 - 5 } & dry & Wet & dry & wet \\
\hline FCNT-rayon nanocomposite & 3.01 & 2.40 & 36.5 & 32.5 \\
nFCNT-rayon nanocomposite & 2.72 & 1.85 & 57.1 & 42.6 \\
Reguler rayon (SNI 14-0938-1989) & $1.2-2.7$ & $0.7-1.8$ & $15-30$ & $20-40$ \\
\hline
\end{tabular}


cellulose xanthate. Because cellulose xanthate is negatively charged polymer, it may be a potential solubilizing agent of CNTs to prepare stable CNT suspensions in water (Wei et al., 2010).

\section{Mechanical Properties of CNTs-Rayon Nanocomposite Filaments}

Mechanical properties are important parameters in evaluating strengh of fiber. The mechanical properties of filaments of FCNT and nFCNT-rayon nanocomposite in the dry and wet state are shown in Table 1. As shown in Table 1, the tenacity value of FCNT-rayon nanocomposite filament increased. High tenacity and elongation of FCNT rayon nanocomposite were provided from good compatibility between rayon matrix and FCNT. The tenacity and elongation in wet state is weaker than that in dry state.

\section{Surface Morphology of FCNTs and nFCNTs Rayon Nanocomposite Filaments}

Cross sectional photo of FCNTs-rayon and nFCNTs-rayon nanocomposite filaments are shown in Fig. 4a and Fig. 4b. The filament shows the skin (outermost layer) of FCNT-rayon more prominent and thicker than the skin of nFCNTrayon. The skin consists of many small crystalline regions. The differences in the ratio of skin to core impact on fiber properties. The thickness of skin contributes to reduce the shrinkage of diameter of fiber. In viscose rayon, the structure and properties of filaments greatly influenced by the spinning process and chemical conditions in the spinning bath (Salihima and Yasin, 1978; Muller et al., 2000). The dilute sulphuric acid decomposes the xanthate and regenerates cellulose by processing of wet spinning. The outer portion of the xanthate was decomposed forming a cellulose skin on the fiber. Sodium and zinc sulphates controlled the rate decomposition of cellulose xanthate to cellulose and fiber formation. Skin formation are influenced by temperature and coagulation solution in the spinning bath. Both FCNT and nFCNT-rayon nanocomposite filaments show the average diameter of 0.3 and $0.2 \mathrm{~mm}$, respectively.

Fig. 5 shows the SEM images of the fracture of FCNTs-rayon nanocomposites fiber with $0.72 \%(\mathrm{w} / \mathrm{w})$ FCNT (a) and nFCNTs rayon

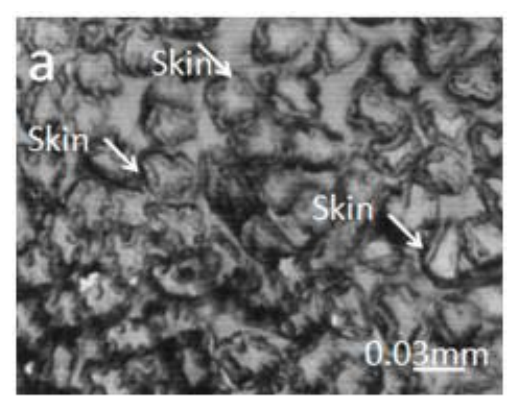

(a)

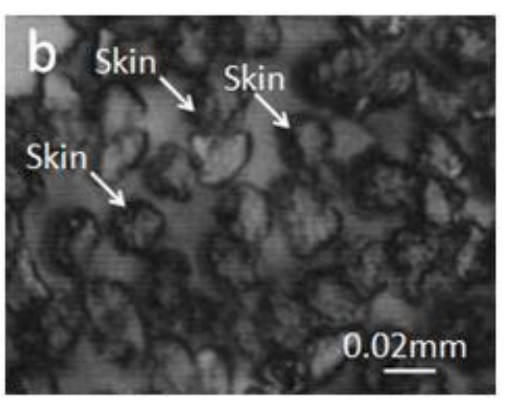

(b)

Figure 4. Cross-Sectional Photo Micrographs of FCNT-Rayon (a) and nFCNT-Rayon(b) Nanocomposite Filament

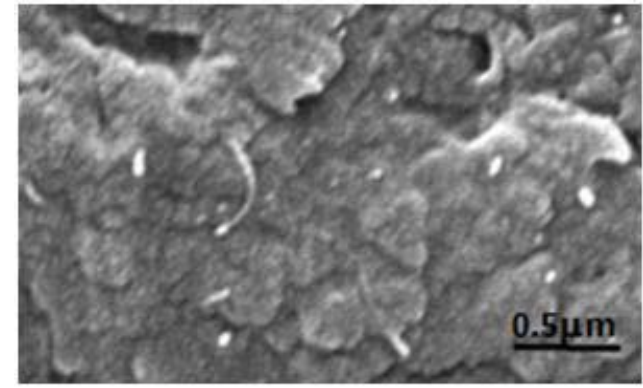

(a)

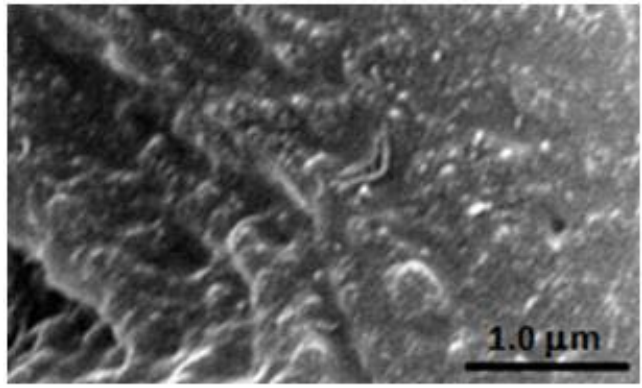

(b)

Figure 5. SEM Image of the Fracture CNT-Rayon Nanocomposite with (a) $0.72 \%$ (w/w) FCNT (b) $0.72 \%(\mathrm{w} / \mathrm{w}) \mathrm{nFCNT}$ 

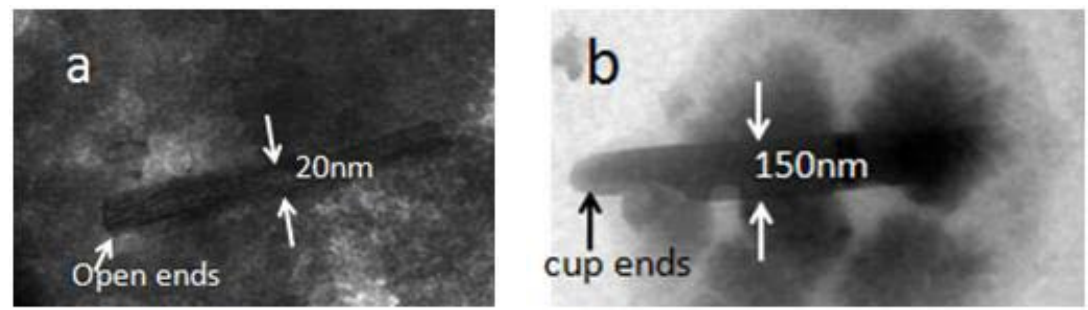

Fig.6 TEM image of (a) FCNT-Rayon Nanocomposite Filament (b) nFCNT-Rayon Nanocomposite Filaments

nanocomposites fiber with $0.72 \%(\mathrm{w} / \mathrm{w}) \mathrm{nFCNT}$ (b). Homogeneous dispersion and exfoliation of FCNT in cellulose matrix were shown in Fig. 5a whereas FCNT are well embedded in cellulose matrix. In the Figure 5b, distribution of nFCNT in the composite is less dense and tend to agglomerate on the surface forming wafe-pattern region.

Analysis of morphological surface by TEM was intended to examine internal structure of composite fiber. In Figure 6a, a clear differences on diameter and surface roughness along the tube wall of fiber are indetified easly. FCNTs have diameter of $20 \mathrm{~nm}$ and open-end fiber. It is reasonable due to functionalization process. Functionalization process caused formation of open-end structure and even structural defect as active site on the surface of fiber. In Fig. 6a, structural defect is shown as surface roughness. Presence of active site on the fiber surface enhance interaction force between CNT and rayon to produce high tenacity composite fiber. In meanwhile, without any active site, shown as smooth surface resulted in lower tenacity composite fiber (Fig. 6b). In this describes an importance of functionalization process subjected to CNT before making composite.

\section{CONCLUSIONS}

CNT-rayon nanocomposite filaments were successfully prepared by addition of $0.72 \%$ $(\mathrm{w} / \mathrm{w})$ CNT in xanthate dissolution process. Functionalized CNTs using $\mathrm{H}_{2} \mathrm{SO}_{4} / \mathrm{HNO}_{3}$ can improve the filterability of the viscose, indicated by decreasing clogging constant $(\mathrm{Kw})$ values from 1689 (nFCNT-viscose) to 155.2 (FCNTviscose). Improvement of mechanical properties occured on the CNT-rayon nanocomposite filaments using functionalized CNT. Mechanical properties of rayon nanocomposite filament using functionalized MWCNT (FCNT) resulted in $3.01 \mathrm{~g} /$ denier (dry tenacity) and $36.5 \%$ (dry elongation) while usage of non functionalized MWCNT (nFCNT) resulted in the mechanical properties of $2.72 \mathrm{~g} /$ denier (dry tenacity), 57.1\% (dry elongation).

\section{ACKNOWLEDGEMENTS}

This research was financially supported by competitive LIPI project. The authors greatly appreciate the help and support of Center for Pulp and Paper, Ministry of Industry, Republic of Indonesia. To Mrs. Susi Sugesty, Mr. Yusuf Setiawan, and Mr. Judi Tjahjono. Thanks for their help.

\section{REFERENCES}

Chen P, Hun-Sik Kim, Soon-Min Kwon, Young Soo Yun, Hyoung-Joon Jin. 2009. Regenerated bacterial cellulose/multi-walled carbon nanotubes composite fibers prepared by wet-spinning. Current Applied Physics. 9:e96-e99.

Clark M.D. 2011. Sachin Subramanian, Ramanan Krishnamoorti. Understanding surfactant aided aqueous dispersion of multi-walled carbon nanotubes. Journal of Colloid and Interface Science. 354:144-151.

Fugetsu B., Sano E., Sunada M, Sambongi Y, Shibuya T, Wang X, Hiraki T. 2008. Electrical conductivity and electromagnetic interference shieding effisiency of carbon nanotube/cellulose composite paper. Carbon; 46:1253-1269.

Iijima S. 1991. 1991. Helical microtubules of graphitic carbon. Nature. 354:56-58

Imai M., Akiyama K., Tanaka T., Sano E. Highly strong and conductive carbon nanotube/ cellulose composite paper. 2010. Composites Science and Technology; 70:1564-1570. 
Moigne N.L, Navard P. 2010. Physics of cellulose xanthate dissolution in sodium hydroxidewater mixtures: a rheo-optical study. Cellulose Chem. Technol. 44 (7-8): 217-221.

Muller M., Riekel C., Vuong R., Chanzy H. 2000. Skin/core micro-structure in viscose rayon fibres analysed by X-ray microbeam and electron diffraction mapping. Polymer. 41:2627-2632

Rausch J., Zhuang R.C., MaderE. 2010. Surfactant assisted dispersion of functionalized multiwalled carbon nanotubes in aqueous media. Composites 2010; Part A 41: 1038-1046

Rike Y, Holia O, Sudirman, Yukie S, Tadashi I and Jun-ichi Azuma. 2011. Analysis of functional group sited on multi-wall carbon nanotube surface. The Open Materials Science Journal. 5:242-247

Salihima A, Yasin F. 1978. Pemilinan viskosa pada suhu kamar. Simposium selulosa dan Kertas II, 3-31 Maret 1978

Sameer S, Rahatekar, Asif Rasheed, Rahul Jain, Mauro Zamarano, Krzysztof K, Koziol, alan H, Windle, Jeffrey W.Gilman, Satish Kumar. 2009. Solution spinning of cellulose carbon nanotube composites using room temperature ionic liquids. Polymer. 50:4577-4583.
Shrivas K., Wu H.F. 2008. Oxidized multiwalled carbon nanotubes for quantitative determination of cationic surfactants in water samples using atmospheric pressure matrix-assisted laser desorption/ionization mass spectrometry. Analytica chimica acta. 628:198-203

Uneback I, Creutz P.A., 1985. Improving Pulp Reactivity with Surface Active Agents in Viscose Production. Lenzinger Berichte. 59:40-44

Wei B., Guan P., Zhang L., Chen G. 2010. Solubilization of carbon nanotubes by cellulose xanthate toward the fabrication of enhanced amperometric detectors. Carbon. 48:1380-1387

Yoon S.H., H.J. Jin, M.C. Kook, Y.R. Pyun. 2006. Electically conductive bacterial cellulose by incorporation of Carbon nanotubes. Biomacromolecules. 7:1280-1284 